\title{
Market-Driven Management in Fashion and Luxury Industries
}

\author{
Fabrizio Mosca *
}

\begin{abstract}
The Market-Driven Management requires that the continuous attention to customers is combined to constant and direct competition in all reference markets.

The Market-Driven Management, in the specific context of companies competing in the fashion and luxury industries can be traced back to three main factors: a growing attention to brand equity; the reinforcement of the direct relationships with final consumers; the improvement of the information flow management system.
\end{abstract}

Keywords: Market-Driven Management; Global Markets; Fashion and Luxury Industries; Brand Equity

\section{Market-Driven Management and Competitive Focus}

The companies that, in the past few years, established themselves as winners of the competitiveness challenge on the global markets have highlighted a distinct ability to adopt a "market-driven orientation".

The Market-Driven Management requires that the continuous attention to customers is combined to constant and direct competition in all reference markets.

Therefore, the Market-Driven Management entails:

- that the organization aspire to a non-stop innovation that must be achieved in a pro-active mode, anticipating competitors' moves, and aiming to identify still dormant, unexpressed or temporarily expressed shares of the market demand;

- that attention is paid to increasing the value of the company's intangible elements as main key factors for a long-term success and as sources of defensible and sustainable competitive advantages.

Companies that can successfully adopt such an approach achieve a higher ability to understand, attract and keep high-profile customers and profitable long-term relationships.

The distinctive characteristics of a market-driven organization are referable to:

\footnotetext{
*Associate Professor of Management, University of Turin (fabrizio.mosca@unito.it)
} 
- a corporate culture that emphasizes the importance of the customer as a reference point;

- a distinct ability to create close and long-term relationships with the market demand in order to be able to perceive even the weak signs and to be flexible and able to anticipate competitors and, last but not least,

- a configuration of the internal organization open to the exterior and highly reactive to the changes of the outer environment. ${ }^{1}$

The aim of this short contribution is to identify, with specific reference to global companies leading the fashion and luxury industries, the main elements of the market-driven approach underlying their lasting competitive advantage.

\section{The Market-Driven Approach in the Fashion and Luxury Industries}

Companies in the fashion and luxury industries ${ }^{2}$ are characterized by: a situation of a dynamic balance between supply and demand; global competition; reduced entry barriers mainly represented by intangible factors; unstable and fast changing demand; globalized value chain; high profitability; importance of the company's country of origin. In this specific context, researches have highlighted that organizations with a market-driven approach have been able to grow and develop.

The Market-Driven Management, in the specific context of companies competing in the fashion and luxury industries and that have won and kept positions of superior competitiveness in the markets, can be traced back to three main factors:

1. a growing attention to increase the value of the main intangible resource represented by the brand equity ${ }^{3}$;

2. the reinforcement of the direct relationships with final consumers with the aim of enhancing their satisfaction, strengthening their identification in the values expressed by the reference brand, increasing their loyalty even in a context of distinct instability and unpredictability of the global demand;

3. the improvement of the information flow management system from the market towards the company, through an internal information system combined with the sales points, and from the company to the market final consumer through personalized interactive and affordable communication.

\section{Increasing the Value of Brand Equity}

In contexts where tangible entry barriers are not significant because of the possible counterfeiting of products or services, the strength of the brand equity is a key factor for success.

Some leading companies in the global market of goods with a highly symbolic value, such as LVMH, Gucci, Bulgari, as well as Technogym, have proved themselves able to develop global brands with an inimitable connecting power ${ }^{4}$ and, consequently, to win shares of the main market areas, achieving a constant growth of turnover and profitability.

In markets with a highly symbolic value, the brand takes on the functions of guidance for the consumer and of buying orientation in every consumer occurrence. 
Once the loyalty relationship has been established, consumers will tend to let the brand itself orient them in the purchase of products that may be varied, because the brand itself identifies the chosen lifestyle. It expresses a value system encoded over time.

Consumers choose a brand if they can recognize in it the ability to represent the lifestyle model that they wish to assert with their purchases. ${ }^{5}$

In the last few years luxury-goods and services successful companies have also exploited brand equity in developing of new product categories through brand extension policies without depriving the brand of its own power. The extension of a well known and solid brand to a new product category allows a low cost fast market penetration, if compared to the investment that a company would bear to develop a new brand. Nevertheless, there is always a problem, especially for companies in the fashion and luxury industries: the brand extension may, at the same time, cause the trivialization of the brand itself affecting the brand equity that was built over time by investing in communication.

This phenomenon is particularly evident for goods with a highly symbolic value, as their long-term competitive chances on the market are closely related to the preservation of their brand equity.

On the other hand, when the market share grows, because of an increase in the sales of the original product or for a brand extension on new products, there is always the risk of trivialization for companies competing in the luxury goods market.

How was it possible for the successful companies in the industries here examined to maintain their competitive advantage based on brand equity?

Leading companies have developed long-term relationships with their customers through a constant innovation of products, style and design and, at the same time, through a strict preservation of brand competitive positioning in the global markets.

\section{Direct Relationships with Consumers Through Distribution}

Maximising consumer satisfaction, strengthening relationships with global market in order to create proactive behaviour, anticipate competitors, and preserve brand equity are the key-factors of market-driven management.

In the specific context of fashion and luxury industries, these aims have also been positively pursued through the management of distribution, that is a strategic variable for a lasting and profitable development of relationships with the market.

Specially, if we focus on distribution coverage and vertical structure of the distribution channels, it is possible to identify distinct trends towards an increase of the direct control of the distribution channel and, at the same time, a selective distribution.

Direct and selective distribution ${ }^{6}$, mainly sole-brand, enable companies to ensure that values of brand equity are preserved also in the distribution, when brand and customer get in touch.

Inside the points of sale consumers can develop relationships which are satisfactory as well as coherent with brand image, as in the directly controlled 
points of sale all the brand values are strictly preserved and there is a basic coherence between them and the values encoded in the consumer's mind.

The growth of market share and profitability, together with preservation of brand equity values are aims that, in the context here examined, must be pursued at the same time, in order to avoid a long-term loss of competitiveness.

The most successful market players have used mainly direct and selective distribution strategies, to pursue objectives both of short-term (for turnover and market share boost) and of long-term (to reinforce brand equity, or to improve customer's profitability) thus plying an excellent market-driven ability.

Points of sale have become the endpoint of the company-customer relationship, where the brand's values are represented.

In the context here examined, companies adopting a market-driven approach and investing in the development of lasting relationships with consumers, have increased the number of direct points of sale in global markets, they have created distribution outlets where customers can relate to the brand through complex multisensorial experiences and have multiplied the contact opportunities with the customers even through the digital channel.

Distribution has not only been used to absolve its primary function of on-theground selling, but also to improve communication.

The emphasis that market-driven companies put on developing lasting relationships with customers has encouraged investments in innovative distribution models, where the communication aspect is very important. Let's consider, for instance, the many flagship-stores for which turnover objectives haven't been set. These outlets are mainly communication windows through which companies get in touch with customers and convey the brand values in a protected context.

\section{Information Flow Management System}

The third element of successful market-driven companies in the examined context, is the ability to manage and coordinate the information flow.

The information flow management has been realized by developing complex information systems that enable a non-stop interchange from and to the reference market.

Successful market-driven companies have created information management systems that:

- $\quad$ are integrated with direct points of sale operating in the global market;

- enable them to obtain a real time information about the main sales figures;

- enable, if necessary, the automatic reordering of the goods;

- can monitor trends of demand, in order to allow real time adjustments of supply.

The most successful companies in the fashion and luxury industries manage the information flow by setting up time-based competition, and it works in two ways, so that it can detect weak signs in the market demand and set up innovative, personalised and affordable supply systems to seize the bubble demand, hence anticipating competitors. 
Information management models used in some fast-fashion businesses, such as Zara, have also been adopted by some more traditional luxury companies, such as LVMH. In this way they improved the response speed to the demand expectations, while developing a more distinct tendency to a non-stop product innovation.

Market-driven companies have also been able to manage the flow of information descending to the final customer.

As already pinpointed, directly controlled points of sale are also employed as communication channels in an integrated communication strategy: distribution takes on innovative functions such as being an information dispenser, giving a stimulus to innovation, and educating about the brand values, it also takes on the responsibility, in the context of top-range goods, of implementing the market-driven approach.

The descending flow of information is more and more personalised and communication is not only interactive but also integrated. The Internet is initially employed as an infomediary to establish relationships with the customers, furthermore, also in the markets of fashion and luxury goods, it has lately become increasingly important as a digital distribution channel in e-commerce actions in the global markets.

In fact, even in the digital channel domain, successful companies were able to recreate through digital technology the buying experience typical of the physical distribution channel ${ }^{7}$.

Market-driven companies in the context here examined were able to combine, inside the organization, the ability to open up and to employ numerous ways of cooperating and interacting with interlocutors ${ }^{8}$.

Coming to a conclusion about the third factor, it is possible to observe that successful companies have implemented highly advanced marketing research competences which consist in spreading inside the organization processes of enhancement of the consumer/product relationship through:

a) acquiring, processing, and sharing information and data inside the organization;

b) reduced times for gathering, processing and employing the information;

c) choosing relevant information to tackle or develop transitory market demand leaps using supply systems significant to consumers through an appropriate management of data-bases where the enterprise and its partners' data are stored. ${ }^{9}$

To sum up, in the specific context of companies competing in the global industries of fashion and luxury goods, pre-eminence in the management of successful companies is strictly related to a market-driven approach, its three key factors are: being able to increase the value of brand-equity; maintaining close direct relationships with consumers through vertical integration end of distribution, also as an element of integrated communication; and adopting efficient information systems to manage the information flow in both directions.

These three factors are not at all disconnected, in fact they are synergetic. Synergy or configuration are necessary to achieve the result of improving the ability to satisfy customers with fast and innovative responses, thus increasing the market share and preserving the value of brand equity. 


\section{Bibliography}

Baccarani C., Golinelli G.M., L’impresa inesistente: relazioni tra immagine e strategia, Sinergie, $\mathrm{n}$. 29, 1999.

Brondoni S.M., Comunicazione, risorse invisibili e strategia competitiva d'impresa, Sinergie, n. 43 44, 1997.

Brondoni S.M., Market-Driven Management ed economia d'impresa globale, AA.VV. (ed.), Market-Driven Management concorrenza e mercati globali, Giappichelli, Turin, 2007.

Cafferata R., Sistemi, ambiente e innovazione. Come s'integrano le continuità e il mutamento d'impresa, II ed., Giappichelli, Turin, 1995.

Coda V., Strategie di comunicazione e immagine, Giappichelli, Turin, 1991.

Collesei U., Marketing, Cedam, Padua, 1989.

Costabile M., Il capitale relazionale, McGraw-Hill, Milan, 2001.

Day G.S., Strategie di mercato e vantaggio competitivo, Isedi, Turin, 1991.

Day G.S., Strategie per i mercati. Processi per la creazione di valore, Etas Libri, Milan, 1992.

Day G.S., Market-Driven Winners, AA.VV. (ed.), Market-Driven Management concorrenza $e$ mercati globali, Giappichelli, Turin, 2007.

Dubois B., Paternault C., Understanding the World of International Luxury Brands: The 'Dream Formula', Journal of Advertising Research, n. 4, 1995.

Golinelli G.M., L'approccio sistemico al governo dell'impresa, vol. 1, L'impresa sistema vitale, Cedam, Padua , 2000.

Golinelli G.M., Ridefinire il valore della marca, Sinergie, n. 63, gennaio-aprile 2004.

Grant R.M., The Resource-Based Theory of Competitive Advantage: Implications for Strategy Formulations, California Management Review, vol. 33, n. 3, 1991.

Gnecchi F., Comunità virtuali, comunità locali e comunicazione pubblica, Sinergie, settembredicembre, 2002.

Guatri L., Vicari S., Fiocca R., Marketing, McGraw-Hill, Milan, 1999.

Lambin J.J., Marketing, McGraw-Hill, Milan, 1991.

Lambin J.J., Market-Driven Management, MacMillan, London, 2000.

Lambin J.J., Marketing strategico e operativo, IV ed., McGraw-Hill, Milan, 2004.

Lorenzoni G., Maneresi A., I processi di internazionalizzazione dell'impresa minore: l'internazionalizzazione attraverso punti di vendita, Sinergie, n. 54, 2001.

Mosca F., Le sinergie di marketing nel settore dei beni di lusso, in Marketing in Mergers and acquisitions - Rapporto sulle sinergie di marketing nelle operazioni di integrazione tra imprese, Facoltà di Economia, Turin, october, 2004.

Mosca F., La strategia di distribuzione dei beni ad elevato valore simbolico, Giappichelli, Turin, 2005.

Mosca F., Strategie di marketing nei mercati del beni ad elevato valore simbolico, AA.VV. (ed.), Strategie di marketing applicate a differenti mercati, Giappichelli, Turin, 2007.

Pellicelli G., Il marketing, Utet, Turin, 1999.

Pellicelli G., Strategia d'impresa, Egea, Milan, 2002.

Pine B.J., Gilmore C., L'economia delle esperienze, Etas, Milan, 2002.

Re P., Il marketing globale, Giappichelli, Turin, 1992. 
Sciarelli S., Vona R., L’impresa commerciale, McGraw-Hill, Milan, 2000.

Valdani E., Marketing strategico. Un'impresa proattiva per sviluppare capacità market driving $e$ valore, Etas Libri, Milan, 1995.

\section{Notes}

1 Cfr. G.S. DAY 2007, Market-Driven Winners, in AA.VV., Market-Driven Management concorrenza e mercati globali, Giappichelli, Turin, pp. 4-5.

2 By convention, the industries of fashion are: clothing, shoes, cosmetics, jewelry, eyewear, watchmaking, leatherwear, and perfumery. In addition to the eight elements mentioned above, identified as the fashion system industries, there are other industries from which goods with a highly symbolic value such as the automotive and nautical industries originated. Besides these, it is necessary to consider luxury services (cruises, hotels and restaurants, first class fights) and top-range foodstuffs (food and wine), not to mention services related to the enjoyment of cultural and artistic heritage. In such sectorial contexts all tendencies of the macro-environmental variables typical of these years clearly emerge, among them: the market and supply globalization, the distribution globalization, the interconnected and global communication, new cultural and social scenes in modern economies, and new consumer trends, Cfr. S.M. Brondoni 2007, Market-Driven Management ed economia d'impresa globale, in AA.VV., Market-Driven Management concorrenza e mercati globali, Giappichelli, Turin, pp. 25-29.

${ }^{3}$ The brand represents a key element in the development process of the company, to the extent that it outlines a virtuous circle based on research and development activities and on communication. In this way, the brand qualifies itself as an intangible resource able to create the conditions for the company profitability. Cfr. G.M. Golinelli 2004, "Ridefinire il valore della marca", in Sinergie, n. 63, gen.-apr., p. 224.

${ }^{4}$ Bernard Arnault, LVMH Group C.E.O. introduced the "star brand" concept to identify the brands whose priority, in the Group, is to concentrate on development: "A star brand is timeless, modern, fast growing and highly profitable. It is very hard to balance all four characteristics at once: fast growing is often at odds with high profitability".

5 Cfr. F. Mosca 2005, La strategia di distribuzione dei beni ad elevato valore simbolico, Giappichelli, Turin, p. 48.

${ }^{6}$ Distribution is intensive when the final product is made available in the largest possible number of sales points, it is selective when the product is made available in an adequate number of sales points, but not all, and it is exclusive when the product is sold only in a few and selected sales points. Cfr. G. Pelliccelli 1999, Il marketing, Turin, Utet, p. 476.

${ }^{7}$ Cfr. F. Mosca 2007, Strategie di marketing nei mercati del beni ad elevato valore simbolico, in AA.VV., Strategie di marketing applicate a differenti mercati, Giappichelli, Turin,, p.157.

${ }^{8}$ Cfr. M.A. Shilling 2007, Gestione delle innovazione, Mc-Graw-Hill, Milan, 2005, p 18; M. Gatti, Cultura d'impresa e concorrenza, in AA.VV., Market-Driven Management concorrenza e mercati globali, Giappichelli, Turin, pp. 152.

${ }^{9}$ Cfr. S.M. Brondoni 2007, Market-Driven Management ed economia d'impresa globale, in AA.VV., Market-Driven Management concorrenza e mercati globali, G. Giappichelli Ed., Turin, pp. 62; F. Gnecchi 2002, Comunità virtuali, comunità locali e comunicazione pubblica, Sinergie, settembre-dicembre. 